УДК 342.92

DOI https://doi.org/10.32837/apdp.v0i90.3203

O.I. Бедний

\title{
ВІДНОСИНИ З ДЕЛЕГУВАННЯ ПОВНОВАЖЕНЬ ЩОДО ПУБЛІЧНОГО АДМІНІСТРУВАННЯ ЯК СКЛАДНИК ПРЕДМЕТА АДМІНІСТРАТИВНОГО ПРАВА
}

Поділ системи права на окремі складові (галузі) пов'язаний із відокремленням певних сукупностей правових норм за специфічними притаманними їм ознаками та характеристиками. Однією з основоположних характеристик, на яких грунтується поділ на галузі права, є предмет регулювання. Предметом визначається як певна сукупність однорідних суспільних відносин, що регулюються нормами відповідної галузі права [1, с. 387; 2, с. 67]. Для адміністративного права визначення предмету регулювання протягом певного часу є сферою наукового переосмислення у зв'язку з трансформацією суспільного призначення цієї галузі, що знаходить своє відображення також у поглядах на його ключові наукові категорії.

Основним елементом предмету адміністративного права є суспільні відносини, які опосередковують публічне адміністрування. Публічне адміністрування, у свою чергу, пов'язане із забезпеченням реалізації публічних (загальних, суспільних) інтересів через постійну, повсякденну діяльність широкого кола суб'єктів, наділених відповідними повноваженнями. Воно охоплює різні напрями діяльності (управлінська, сервісна тощо) та передбачає різний ступінь впливу та втручання суб'єктів адміністрування у діяльність інших осіб. Публічне адміністрування історично розглядалося в основному як сфера реалізації функцій та повноважень органів державної влади (насамперед, виконавчої влади) та органів місцевого самоврядування. Російський автор Г.В. Атаманчук, аналізуючи державне управління, що є найбільш дослідженою складовою частиною публічного адміністрування, звертав увагу на те, що організаційна структура державного управління підключає до цієї діяльності практично всі органи державної влади і місцевого самоврядування, які беруть участь у формуванні та реалізації державно-управлінських впливів [3, с. 200].

Сучасні українські вчені С.В. Ківалов та Л.Р. Біла-Тіунова відзначають, що інститут «делегування державних повноважень», не будучи новизною для теорії адміністративного права, тільки останнім часом почав належно формуватися, особливо в плані нормативно-правового забезпечення [4, с. 7]. Провідний український науковець В.Б. Авер'янов, у свою чергу, визначив, що до предмету адміністративного права входять, зокрема, суспільні відносини, що формуються у ході реалізації повноважень виконавчої влади, делегованих державою органам місцевого самоврядування, громадським організаціям та деяким іншим недержавним інституціям [2, с. 71].

Російський вчений Ю.О. Тихомиров відзначив, що державно-правове регулювання економіки включає і механізм публічної участі в комерційній діяльності, при цьому гнучкий вибір форм публічної участі створює для суспільства і корпора-

(c) О. І. Бедний, 2021 
тивних структур умови і режими ефективної діяльності [5, с. 208]. В.П. Тимощук пропонує як певну альтернативу децентралізації повноважень з надання адміністративних послуг або паралельний напрямок покращення їх якості розглядати i «приватизацію послуг» та/або впровадження конкуренції [6, с. 119].

Т.О. Карабін підкреслює, що інститут делегування повноважень розширює суб'єктний склад публічної влади. Вона звертає увагу, що публічна влада здійснюється у різноманітних формах широким колом суб'єктів, починаючи від органів державної влади та закінчуючи окремими фізичними особами, тому включає до публічної адміністрації як органи державної, насамперед, виконавчої влади, і органи місцевого самоврядування, так і приватних осіб (фізичних та юридичних), які беруть участь у реалізації лише частини публічно-владних функцій [7, с. 13].

Н.В. Галіцина відмітила, що згідно з концепцією Г. Вільсона держава передає приватному сектору ряд своїх функцій лише тому, що це допомагає ефективніше вирішувати соціальні та економічні проблеми. Скорочення функцій, що виконуються державою, дозволяє їй зосередитись на таких важливих питаннях, як контроль за бюрократією та ключові стратегічні напрямки державного управління [8, с. 83]. На основі свого аналізу вона дійшла висновку, що делегування повноважень включає два підінститути: делегування повноважень від одного органу публічної влади іншому та делегування державних повноважень приватним структурам.

Німецький дослідник адміністративного комерційного права (нім. Wirtschaftsverwaltungsrecht) Рольф Штобер вказує, що делегування прагне децентралізувати публічне адміністрування, позбавити органи публічної влади від надмірних функцій, використовувати приватну ініціативу та менеджерські навички, щоб забезпечити найбільш ефективне використання фінансових ресурсів, технічної та іншої експертизи. Говорячи про механізм делегування, він зазначив, що делегування здійснюється за законом, за адміністративним актом на основі закону або за адміністративно-правовим договором. Заслуговує на увагу позиція автора, згідно з якою делегування повноважень слід відрізняти від виконання публічних завдань в силу так званого обов'язку здійснювати матеріальну або особисту участь на користь органів публічної влади. Суб'єкт господарювання, який бере на себе такі обов'язки, не виконує публічних функцій. Він виконує певні обов'язки, керуючись суспільними інтересами, і тим самим допомагає відповідним органам здійснювати публічне адміністрування [9, с. 343-344].

Тулик I.I., досліджуючи конституційно-правові засади делегування повноважень як форми взаємодії органів публічної вади, відзначає, що делегування є процесом, за допомогою якого здійснюється поділ сфери між органами. Він обов'язковий для будь-якого органу чи державної влади чи органу місцевого самоврядування. Повноцінне, ефективне, раціональне виконання тих чи інших завдань як таке неможливе без делегування повноважень. Автор робить висновки, що делегування: а) має базуватися на вільній згоді обох суб'єктів делегування; б) повинно супроводжуватися укладенням відповідного договору; в) має обов'язково мати фінансове та матеріальне забезпечення для належної реалізації делегованим суб'єктом делегованих повноважень; г) переделегування (субделегування) 
повноважень не допускається, бо це суперечить цілям і намірам органу, що делегує повноваження; д) делегований суб'єкт несе юридичну відповідальність за належне виконання делегованих повноважень [10, с. 124-125].

Таким чином, нерідко делегування повноважень щодо публічного адміністрування розглядається в межах виконавчої гілки державної влади та місцевого самоврядування. В Україні, зокрема, з початку 90 -х років ХХ століття були зроблені значні кроки щодо деконцентрації та децентралізації публічних адміністративних функцій. Чинне українське законодавство про місцеве самоврядування та місцеві державні адміністрації містить різні положення щодо здійснення повноважень: а) делегованих органами державної виконавчої влади виконавчим органам місцевих (міських, селищних та сільських) рад; б) делегованих обласними та районними радами відповідним місцевим державним адміністраціям. Публічне адміністрування або певні пов'язані з ним функції можуть здійснювати інші суб'єкти, які не є органами державної влади чи місцевого самоврядування.

У теперішній час можна звертати увагу на питання, пов'язані з делегуванням повноважень у публічному адмініструванні, які в основному або ігноруються, або лише частково охоплюються чинним українським законодавством, такі як: а) визначення загального кола суб'єктів, які можуть здійснювати делеговані повноваження; б) встановлення загальних та, за необхідності, спеціальних умов для участі таких суб'єктів у здійсненні відповідних повноважень; в) забезпечення підзвітності, контролю, обміну інформацією під час здійснення делегованих повноважень, а також юридичної відповідальності за порушення при їх здійсненні; г) фінансове та інше ресурсне забезпечення здійснення делегованих повноважень тощо. Однак навіть у законопроекті «Про порядок делегування повноважень органів виконавчої влади та органів місцевого самоврядування» [11] не згадуються, наприклад, недержавні структури як суб’єкти, які можуть здійснювати делеговані повноваження органів публічної влади.

Можна спробувати визначити окремі причини, чому українські законодавці до цих пір не визначили набір універсальних правил делегування публічно-владних повноважень (зокрема, щодо публічного адміністрування), зокрема, суб'єктам, які не є органами публічної влади. По-перше, Конституція України передбачає, що суверенітет народу України здійснюється органами державної влади та органами місцевого самоврядування [12]. Як такі, ці органи утворюють більшменш ієрархічну систему із внутрішньою підпорядкованістю та координацією. Ті органи публічної влади, які здійснюють публічне адміністрування (це, насамперед, органи виконавчої влади у системі державної влади та виконавчі органи у системі місцевого самоврядування), підзвітні людям безпосередньо або через представницькі органи влади. Жодного такого рівня підпорядкування та підзвітності широкій громадськості не існує у приватному бізнесі або в громадських об'єднаннях та інших некомерційних організаціях (НКО). По-друге, суб'єкти підприємництва та НКО мають певні власні цілі створення та існування. Суб’єкти підприємництва здійснюють діяльність задля отримання прибутку, тоді як, наприклад, громадські об'єднання забезпечують задоволення соціальних, культурних, екологічних та інших потреб своїх членів. Вони не зобов'язані діяти в публічних інтересах, оскільки досягнення суспільного блага не є їх основною метою. 
Водночас, на нашу думку, наявність наведених вище проблем не перешкоджає науковому осмисленню та законодавчому упорядкуванню делегування повноважень щодо публічного адміністрування недержавним суб'єктам. Перспективними сферами такого делегування можуть вважатися: 1) надання адміністративних послуг, коли за рахунок розширення кола суб’єктів підвищується їх доступність; 2) здійснення окремих публічно-адміністративних функцій саморегулівними організаціями; 3) здійснення окремих контрольно-наглядових функцій представниками фахових громадських об'єднань (наприклад, екологічного спрямування); 4) використання механізму соціального замовлення для надання соціальних послуг тощо.

Убачається, що суспільні відносини 3 делегування повноважень слід розглядати як окрему складову частину предмету адміністративного права, яка має допоміжний характер щодо публічно-управлінських та публічно-сервісних відносин. Основним призначенням адміністративно-правового регулювання відносин з делегування повноважень необхідно вважати визначення необхідних меж та засобів здійснення публічно-адміністративної (управлінської та сервісної) діяльності учасниками суспільних відносин, які не є первісними носіями відповідних повноважень органів публічної влади. При цьому такі відносини опосередковують як самі умови та інструменти делегування повноважень, так і окремі питання, безпосередньо пов'язані з реалізацією делегованих повноважень.

На нашу думку, серед відносин з делегування повноважень щодо публічного адміністрування можна виділити такі:

1. Основне відношення 3 делегування повноважень, у якому беруть участь орган публічної влади, повноваження якого делегуються, та інший суб'єкт, який набуває відповідні повноваження у порядку делегування. У межах цього відношення орган публічної влади передає, а інший суб'єкт набуває повноваження. Обов'язковим учасником такого відношення є орган публічної влади, наділений повноваженнями щодо публічного адміністрування. Іншим учасником може бути орган публічної влади (державної влади або місцевого самоврядування), суб'єкт господарювання, особа, яка здійснює незалежну професійну діяльність, громадське об'єднання тощо.

2. Відносини щодо матеріально-технічного, інформаційного, фінансового та іншого ресурсного забезпечення делегування повноважень. Ці відносини пов'язані з визначенням ресурсів, необхідних для реалізації делегованих повноважень. Зокрема, передбачаються джерела таких ресурсів, способи їх передачі або надання доступу до них суб’єкту, який здійснює делеговані повноваження. Ухвалення рішень щодо делегування повноважень має здійснюватися з огляду на ресурсоємність делегування повноважень та їх реалізації. Також мають братися до уваги інші фактори, наприклад, забезпечення доступності адміністративних послуг для їх споживачів.

3. Відносини щодо контролю суб'єкта делегування та громадянського суспільства за реалізацією делегованих повноважень. У межах цієї групи відносин застосовуються методи, форми та процедури, за допомогою яких суб'єкт делегування та інститути громадянського суспільства можуть визначити стан реалізації делегованих повноважень, кількісні та якісні параметри динаміки суспільних відносин 
у сфері, де здійснюється делегування повноважень. Також визначаються та використовуються необхідні засоби впливу у разі відхилення від встановлених вимог під час реалізації делегованих повноважень.

4. Відносини щодо захисту інформації під час реалізації делегованих повноважень. На нашу думку, делегування повноважень має бути обмежене тими сферами, які не передбачають використання та обробку інформації, що становить державну таємницю. У разі використання іншої інформації з обмеженим доступом у межах даної групи відносин має передбачатися та дотримуватися відповідний режим такої інформації, що унеможливить її використання не за призначенням.

Підсумовуючи вищенаведене, відносини з делегування повноважень щодо публічного адміністрування є окремою складовою частиною предмету адміністративного права, яка спрямована на підвищення ефективності реалізації відповідних повноважень з метою забезпечення дотримання публічних інтересів та створення умов для реалізації відповідних прав фізичних і юридичних осіб.

\section{Jimepamypa}

1. Скакун О.Ф. Теория государства и права (энциклопедический курс) : учебник. Харьков : Эспада, $2005.840 \mathrm{c.}$

2. Адміністративне право України. Академічний курс : підруч. : у двох томах: Том 1. Загальна частина / Ред. колегія: В.Б. Авер'янов (голова). Київ : Видавництво «Юридична думка», 2004. 584 с.

3. Атаманчук Г.В. Теория государственного управления : Курс лекций. 3 -е изд., доп. Москва : Изд-во ОМЕГА-Л, 2005. 584 с.

4. Ківалов С.В., Біла-Тіунова Л.Р. Адміністративне право України : навчальний посібник. 5-е вид., перероб. і доп. Одеса : Фенікс, 2011. 400 с.

5. Теория компетенции / Ю.А. Тихомиров. Москва : Изд-во Тихомирова М.Ю., 2001. 355 с.

6. Тимощук В.П. Адміністративні послуги: проблеми теорії, законодавства і практики в Україні. Адліністративне право і процес. 2014. № 3(9). Ювілейний. С. 104-120.

7. Карабін Т.О. Розподіл повноважень публічної адміністрації : монографія. Ужгород : Гражда, 2016. $220 \mathrm{c}$.

8. Галіцина Н.В. Основні положення теорії делегування повноважень у сфері соціальної політики. Науковий вісник Ужгородського національного університету. Серія ПРАВО. 2015. Випуск 35. Частина II. Том 2. С. 80-85.

9. Штобер, Рольф. Хозяйственно-административное право. Основы и проблемы. Мировая экономика и внутренний рынок = Allgemeines Wirtschaftsverwaltungsrecht. Grundlagen des Wirtschaftsverfassungs- und Wirtschaftsverwaltungsrechts, des Weltwirtschafts und Binnenmarktrechts; пер. с нем. Москва : Волтерс Клувер, 2008. 400 с.

10. Тулик I.I. Конституційно-правові засади делегування повноважень як форма взаємодії органів публічної влади : дис. ... канд. юрид. наук : 12.00.02. Ужгород, 2016. 223 с.

11. Про порядок делегування повноважень органів виконавчої влади та органів місцевого самоврядування : Проект Закону України від 01.02.2008 p. № 1472. URL : http://zakon.rada.gov.ua.

12. Конституція України від 28.06.1996 p. URL : http://zakon.rada.gov.ua. 


\section{Анотація}

Бедний О. I. Відносини з делегування повноважень як складник предмета адміністративного права. - Стаття.

У статті розглядаються теоретичні та практичні засади делегування повноважень щодо публічного адміністрування, а також їх адміністративно-правове регулювання. Встановлено, що під час переосмислення суспільного призначення адміністративного права відповідні суспільні відносини розглядаються більшістю дослідників як елемент предмету цієї галузі. Ці відносини є допоміжними щодо відносин, які опосередковують публічне адміністрування: публічно-управлінських та публічно-сервісних.

Взято до уваги, що в Україні з початку 90 -х років XX століття були зроблені значні кроки щодо деконцентрації та децентралізації публічних адміністративних функцій. Це стосується делегування повноважень органів виконавчої влади органам місцевого самоврядування (виконавчим органам місцевих рад), а також делегування повноважень обласних та районних рад відповідним місцевим державним адміністраціям. Визначено проблеми адміністративно-правового регулювання делегування повноважень, пов'язані, зокрема, з відсутністю основоположного законодавчого акта, який упорядковує відповідні питання. Запропоновані перспективні сфери, у яких може здійснюватися делегування повноважень щодо публічного адміністрування приватним (недержавним) суб'єктам.

Охарактеризовано види суспільних відносин щодо делегування повноважень, які можна розглядати в контексті предмету адміністративного права: 1) основне відношення з делегування повноважень; 2) відносини щодо матеріально-технічного, інформаційного, фінансового та іншого ресурсного забезпечення делегування повноважень; 3) відносини щодо контролю суб'єкта делегування та громадянського суспільства за реалізацією делегованих повноважень; 4) відносини щодо захисту інформації під час реалізації делегованих повноважень.

Зроблено висновок, що відносини з делегування повноважень щодо публічного адміністрування як складова частина предмету адміністративного права створюють умови для підвищення ефективності реалізації відповідних повноважень із метою забезпечення здійснення публічно-адміністративної діяльності та реалізації інших функцій органів публічної влади.

Ключові слова: адміністративне право, предмет адміністративного права, органи публічної влади, суспільні відносини, делегування повноважень, децентралізація

\section{Summary}

Bednyi O. I. Relations on delegation of powers as a component of the subject of administrative law. Article.

The article considers the theoretical and practical principles of delegation of powers for public administration, as well as their regulation in administrative law. It is established that during the rethinking of the public purpose of administrative law, the relevant social relations are considered by most researchers as an element of the subject of this field of law. These relations are ancillary to the relations that constitute public administration, including public management and delivery of administrative services.

It is taken into account that significant steps have been taken in Ukraine since the early 1990 s to deconcentrate and decentralize public administrative functions. This applies to the delegation of powers of state executive bodies to local self-government (executive bodies of local councils), as well as the delegation of powers of regional and district councils to the relevant local state administrations. There are certain problems administrative law regulations of delegation of powers, related, in particular, to the lack of a core legislative act regulating the relevant issues. Promising areas in which the delegation of public administration powers to private (non-state) entities can be carried out are proposed.

The types of social relations concerning delegation of powers which can be considered in the context of a subject of administrative law are characterized: 1) the basic relation on delegation of powers; 2) relations on logistical, informational, financial and other resource support of delegation of powers; 3) relations on the control of the subject of delegation and civil society over the implementation of delegated powers; 4) relations on information protection during the exercise of delegated powers.

The conclusion is that the relations of delegation of powers for public administration as a component of the subject of administrative law create conditions for improving the implementation of relevant powers to ensure the implementation of public administration and other functions of public authorities.

Key words: administrative law, subject of administrative law, public authorities, relations in society, delegation of powers, decentralization. 